\title{
Biomass, metabolism and nutrition of zooplankton in the Gulf of Lions (NW Mediterranean)
}

\section{Biomasse, métabolisme et nutrition du zooplancton dans le Golfe du Lion (Méditerranée nord-occidentale)}

\author{
Raymond Gaudy ${ }^{\mathrm{a}, *}$, Faïçal Youssara ${ }^{\mathrm{a}}$, Frédéric Diaz ${ }^{\mathrm{b}}$, Patrick Raimbault ${ }^{\mathrm{b}}$ \\ ${ }^{a}$ Centre d'Océanologie de Marseille, LOB, (URA CNRS 6535), Station marine d'Endoume, rue de la batterie des lions, 13007 Marseille, France \\ ${ }^{b}$ Laboratoire d'Océanographie de Biogéochimie, Campus de Luminy, 13288 Marseille cedex 09, France
}

Received 30 September 2001; received in revised form 1 February 2002; accepted 11 February 2002

\begin{abstract}
Zooplankton biomass was measured at 20 stations located along five coastal-offshore transects in the Gulf of Lions (NW Mediterranean) during spring 1998 and winter 1999, using two nets equipped with 200 and $80 \mu \mathrm{m}$ mesh. Biomass was twice as abundant in spring. It increased toward the coast and the west of the gulf and was positively correlated to chlorophyll, primary production and organic particulate matter and negatively to temperature and salinity. The enrichment effect of Rhone river input and the oligotrophic influence of the north Mediterranean current (NMC) were the main distribution factors of zooplankton biomass. Higher biomass was obtained in coastal stations with the $80 \mu \mathrm{m}$ net, which sampled more efficiently young larval stages and nauplii. Zooplankton metabolic activity (respiration, ammonium and phosphorus excretion) was studied at the inner and outer stations of each transect. Oxygen/nitrogen $(\mathrm{O} / \mathrm{N})$ ratio was lower in spring than in winter, indicating that more protein material was used for food, to complete the energy needed for the spring enhancement of secondary production. Nitrogen and phosphorus excreted by zooplankton accounted for $31 \%$ and $10 \%$ of the primary production requirements in spring and for $32 \%$ and $>100 \%$, in winter. Grazing impact and secondary production were calculated from respiratory requirements using a $K_{2}$ value of 0.4 and an assimilation rate of 0.8 . Grazing impact ranged between $9 \%$ and $69 \%$ of the primary production in spring and between $6 \%$ and $83 \%$ in winter, depending on the stations. The average secondary production was $54 \mathrm{mg} \mathrm{C} \mathrm{m}^{-2} \mathrm{~d}^{-1}$ in spring and $19 \mathrm{mg} \mathrm{C} \mathrm{m}^{-2} \mathrm{~d}^{-1}$ in winter, which represents $11 \%$ and $12 \%$ of the primary production, respectively.
\end{abstract}

(C) 2003 Éditions scientifiques et médicales Elsevier SAS and Ifremer/CNRS/IRD. All rights reserved.

Résumé

La biomasse du zooplancton a été mesurée à vingt stations disposées le long de cinq radiales côte-large dans le golfe du Lion (Méditerranée occidentale), au printemps 1998 et en hiver 1999, en utilisant deux filets équipés de mailles de 200 et de $80 \mu$ m. La biomasse était deux fois plus élevée au printemps. Elle augmentait vers la côte et vers l'ouest du golfe et était corrélée positivement à la chlorophylle, à la production primaire et à la matière organique particulaire et négativement à la température et à la salinité. L'enrichissement par les apports du Rhône et l'influence oligotrophique du courant nord Méditerranéen étaient les principaux facteurs de distribution de la biomasse zooplanctonique. Des biomasses plus élevées ont été obtenues dans les stations côtières avec le filet $80 \mu \mathrm{m}$ qui échantillonne plus efficacement les jeunes stades larvaires et les nauplii. L'activité métabolique du zooplancton (respiration, excrétion d'ammonium et de phosphore) a été étudiée aux stations distale et proximale de chaque radiale. Le rapport oxygène/azote $(\mathrm{O} / \mathrm{N})$ était plus bas au printemps qu'en hiver, indiquant que plus de matériel protéinique était utilisé comme nourriture pour compléter l'énergie nécessitée à l'accroissement printanier de la production secondaire. L'azote et le phosphore excrétés par le zooplancton représentent $31 \%$ et $10 \%$ des besoins de la production primaire au printemps et $32 \%$ à $>100 \%$, en hiver. L'impact de broutage et la production secondaire ont été calculés à partir des besoins respiratoires en utilisant une valeur de $K_{2}$ de 0.4 et un taux d'assimilation de 0,8 . L'impact de broutage variait de $9 \%$ à $69 \%$ de la production primaire au printemps et de $6 \%$ à $83 \%$

\footnotetext{
* Corresponding author.

E-mail address: gaudy@ com.univ-mrs.fr (R. Gaudy).
} 
en hiver, selon les stations. La production secondaire moyenne était de $54 \mathrm{mg} \mathrm{C} \mathrm{m}^{-2} \mathrm{~d}^{-1}$ au printemps, et de $19 \mathrm{mg} \mathrm{C} \mathrm{m}^{-2} \mathrm{~d}^{-1}$ en hiver, ce qui représente respectivement $11 \%$ et $12 \%$ de la production primaire.

(C) 2003 Éditions scientifiques et médicales Elsevier SAS and Ifremer/CNRS/IRD. All rights reserved.

Keywords: Zooplankton; Metabolism; Seasonal cycle; Gulf of Lions

Mots clés : Zooplankton ; Métabolisme ; Cycle saisonnal ; Golfe du Lion

\section{Introduction}

Continental margins are generally considered as highly productive areas when compared to open ocean. The enhancement of the biological productivity is the consequence of nutrient inputs from land or from coastal upwelling. The proximity of the coast line, the shallowness of the water column, the local decreases of salinity due to freshwater discharges and the advective effects of coastal currents contribute to the variable character of the coastal environment contrasting with the more steady features of the open sea. The zooplankton inhabiting these different hydrological structures is submitted to variable environmental and food conditions susceptible to modify its metabolism and its feeding behavior and finally, its capacity to produce. In the Mediterranean Sea, the Gulf of Lions differentiates from most other coastal zones by the existence of an enlarged continental shelf reaching up to 40 miles width. It is strongly influenced by the input of the Rhone river and by the north Mediterranean current (NMC). The Rhone discharge creates a current flowing southwards then, rapidly deviating westwards, due to the Coriolis effect and the general circulation. The plume extent, linked to the river flow (Morel et al., 1990), is relatively limited (10-20 km) but the dilution zone due to the Rhone freshwater input can influence more distant areas, such as the north western part of the Gulf (Languedoc littoral zone), and in some cases, the Roussillon coast, near the Spain boundary (Tournier, 1969; Minas and Minas, 1989). The NMC, when entering the Gulf, divides into two branches. The southern one flows along the continental slope while the northern penetrates the shelf, adopting a NW direction (Millot and Wald, 1980). Moreover, coastal upwellings induced by strong north winds are frequent (Minas, 1968; Tournier, 1969; Millot, 1979). Temporal variations, mostly linked to winds or to the Rhone river flow, can modify the characteristics of these different hydrodynamic features (Furnestin, 1960; Millot and Wald, 1980). In the Gulf of Lions, several previous studies refer to different characteristics of the pelagic environment such as current circulation (Millot and Crepon, 1990), hydrology (Furnestin, 1960), nutrients distribution (Coste, 1974; Coste et al., 1977) or primary production (Minas and Minas, 1989; Lefèvre et al., 1997; Conan et al., 1998). The variations of zooplankton biomass were studied by Razouls and Kouwenberg (1993) at the scale of the whole gulf and along coastal-offshore transects by Gaudy and Champalbert (1998) and Plounevez and Champalbert (2000). Generally, pelagic assemblages and productivity are strongly dependent on eutrophic continental inputs and hydrodynamism (Péres, 1982). The goal of the present study is (1) to examine the effect of hydrological variability on the standing stock and the physiological activity of zooplankton in the Gulf of Lions and (2) to quantify the relations existing between the primary and secondary levels of the food chain, concerning zooplankton grazing activity and the role of zooplankton as a complementary nutrient provider for primary production, via its excretion process.

\section{Materials and methods}

The results concern two seasonal cruises in the Gulf of Lions: Moogli 1 (10 March-15 April 1998) aboard R.V. L'Atalante and Moogli 3 (10-21 January 1999), with R.V. Le Noroît. During these cruises, the same standard sampling plan was adopted. It consisted of five transects between the coast and the open sea (numbered 1 to 5 from the east of the zone), with four stations per transect (Fig. 1). Other complementary stations were also explored for different purposes, to complete the geographical survey of the gulf; but were not used for the present study. Zooplankton was sampled vertically between $200 \mathrm{~m}$ (or the bottom) and the surface, at different time of the day. As most of the vertical migration occurs in the upper $200 \mathrm{~m}$ (Boucher and Thiriot, 1972) no variation in zooplankton biomass related to nycthemeral cycle was expected. Three WP2 nets (UNESCO, 1968) fitted on a common frame were used. Two nets were equipped with a silk of $200 \mu \mathrm{m}$-mesh size and the third, with a silk of 80 $\mu \mathrm{m}$-mesh size. For biomass measurements, half of samples of the $70 \mu \mathrm{m}$ net and of one of the $200 \mu \mathrm{m}$ nets were sieved on a pre-weighed filtering disk of the corresponding porosity, rapidly rinsed with distilled water then frozen. Later, at the land laboratory, samples were defrosted, dried in an oven $\left(70{ }^{\circ} \mathrm{C}, 24 \mathrm{~h}\right)$ and weighed. Dry-weight of samples was measured from the difference between the final weight and the weight of the disk and extrapolated to the volume sampled by the net to calculate the standing stock. The rest of the sample was preserved in buffered $4 \%$ formaldehyde and stored for subsequent identification and counting of the organisms.

The material collected by the second $200 \mu \mathrm{m}$ net was reserved for shipboard experiments. Zooplankton was cleared from detritus and gelatinous material (salps, siphonophores, and meduses) and fractionated into 10 parts. For incubation experiments, eight $300 \mathrm{ml}$ bottles were filled with seawater filtered on a $0.45 \mu \mathrm{m}$ membrane (FW series) and 


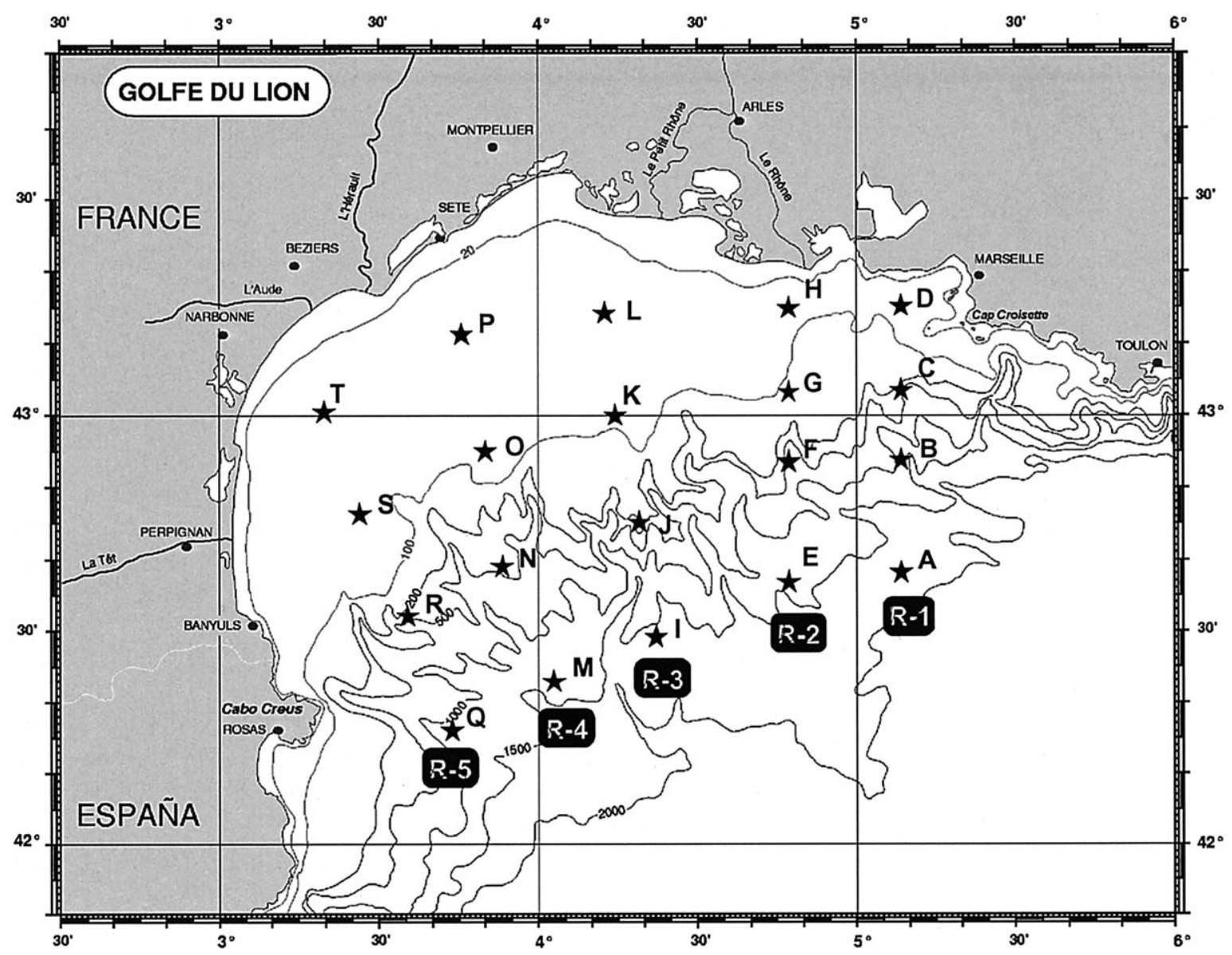

Fig. 1. Map of the Gulf of Lions and location of the stations.

eight other bottles, with unfiltered seawater coming from the surface (UFW series). For each series, zooplankton aliquots were introduced in five of the bottles, while the three others, without zooplankton, served as controls. Incubation lasted about $24 \mathrm{~h}$, at sea temperature and in the dark. Bottles of the UFW series were fixed on a vertically rotating wheel ( $2 \mathrm{rpm})$ to avoid the sedimentation of particles. At the end of the incubation period, $30 \mathrm{ml}$ of water was withdrawn from each bottle and measured for oxygen concentration (oxymeter YSI 53). In the FW series, two other $30 \mathrm{ml}$ volumes were taken for ammonium measurement, according to Koroleff's method (Koroleff, 1969) and for phosphate measurement (Strickland and Parson, 1972). Finally, $100 \mathrm{ml}$ of water were taken from the bottles of the UFW series and conserved in plastic flasks with 15 drops of filtered formaldehyde for the determination of particle concentration, using the Coulter Counter technique. Although it is preferable to determine the particles' spectrum immediately, without preservation, formaldehyde does not alter significantly the total volume of particles in a sample (Pagano, personal communication). Zooplankton from the different experimental flasks was then collected by sieving, dried in an oven then weighed. Thus, respiratory, excretory and ingestion rates could be related to animal weight and presented as specific values.

For each cruise, zooplankton biomass was measured at each of the 20 standard stations. Incubation experiments, which needed a rather long time for preparation and measurement, were carried out only at the extreme stations (proximal and distal) of each transect.

Vertical profiles of temperature and salinity values were obtained using a CTDO Seabird (model SBE 911). Samples for chlorophyll $(250 \mathrm{ml})$ were filtered immediately onto baked $\left(450^{\circ} \mathrm{C}\right.$ for $24 \mathrm{~h}$ ) Wathman GF/F filters. Chlorophyll $a$ concentration was estimated on board using the fluorometric technique by Yentsch and Menzel (1963) and methanol extraction according to Raimbault et al. (1988). Particular organic carbon (POC) and particular organic nitrogen (PON) were analyzed by the wet oxidation method, according to Raimbault et al. (1999). Primary production was determined using the ${ }^{14} \mathrm{C}$-technique (Steeman-Nielsen, 1952) with the experimental protocol of Fiztwater et al. (1982). Samples were incubated under in situ simulated conditions for $12 \mathrm{~h}$ in deck incubators cooled by surface seawater.

\section{Results}

\subsection{Environmental factors}

Vertical profiles of temperature, salinity and chlorophyll at the different stations of each cruise are presented on Figs. $2-4$. Fig. 5 resumes the average conditions occurring during 
Temp rature $(i \mathrm{C})$
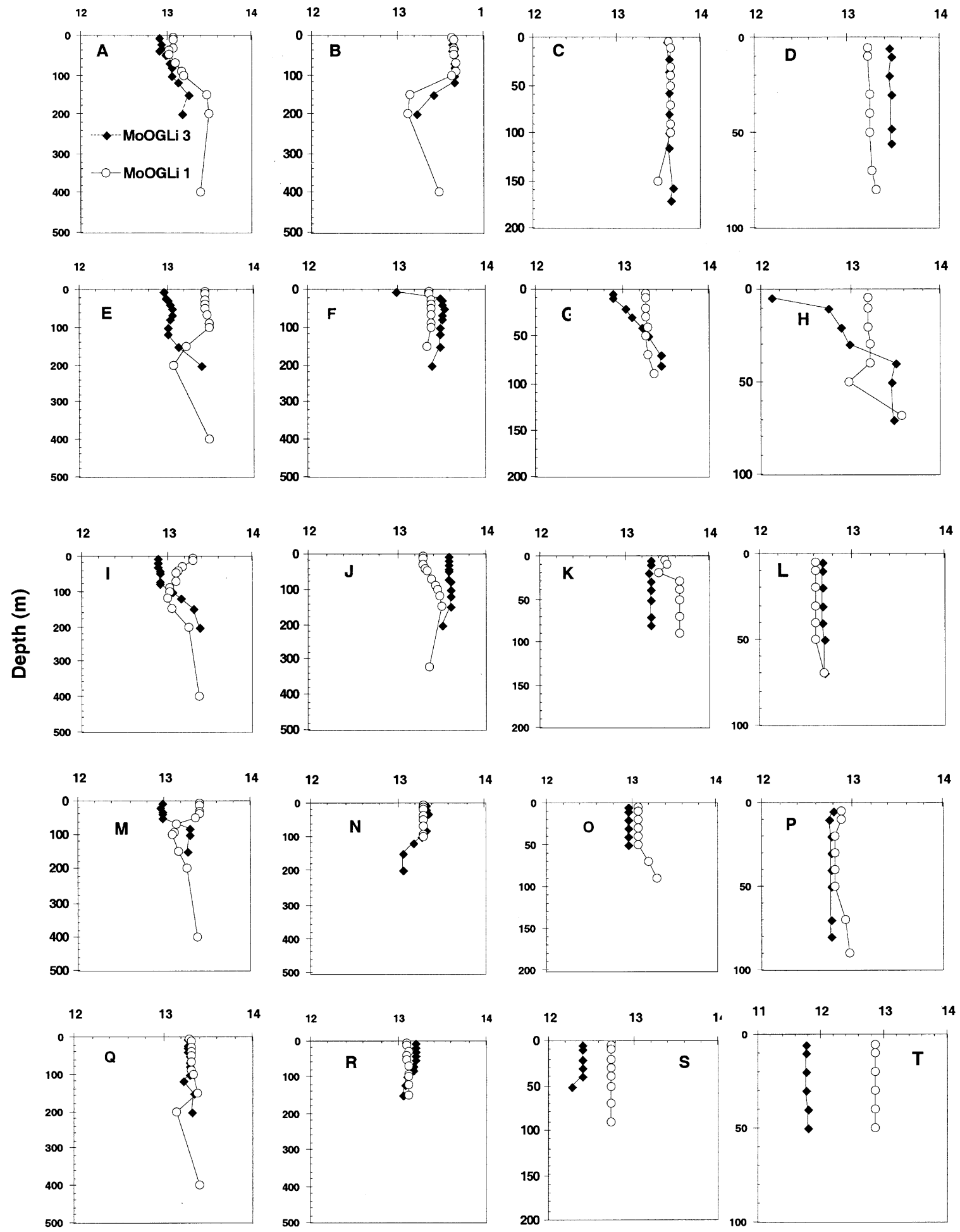

Fig. 2. Vertical profiles of temperature at the different stations of Moogli 1 and 3 cruises.

Moogli 1 and 3 between 0 and $100 \mathrm{~m}$. Average temperatures were very close $\left(13.18\right.$ and $13.08{ }^{\circ} \mathrm{C}$, respectively). Temperature tended to decrease from the east to the west of the gulf, and also from offshore to the coast. Mean salinity was slightly more elevated during Moogli 3 (38.13 instead of 37.98). For each cruise, salinity values decreased slightly towards the west and from offshore to the coast. Their lowest values were observed close to the coast in the middle of the gulf (transect 3) during Moogli 1, or near the Rhone river delta (station $\mathrm{H}$ ) during Moogli 3. For both cruises, highest POC, PON and C/N values were found at transect 3 (Fig. 5). Average chlorophyll concentration (Fig. 6) was similar for 
Salinit
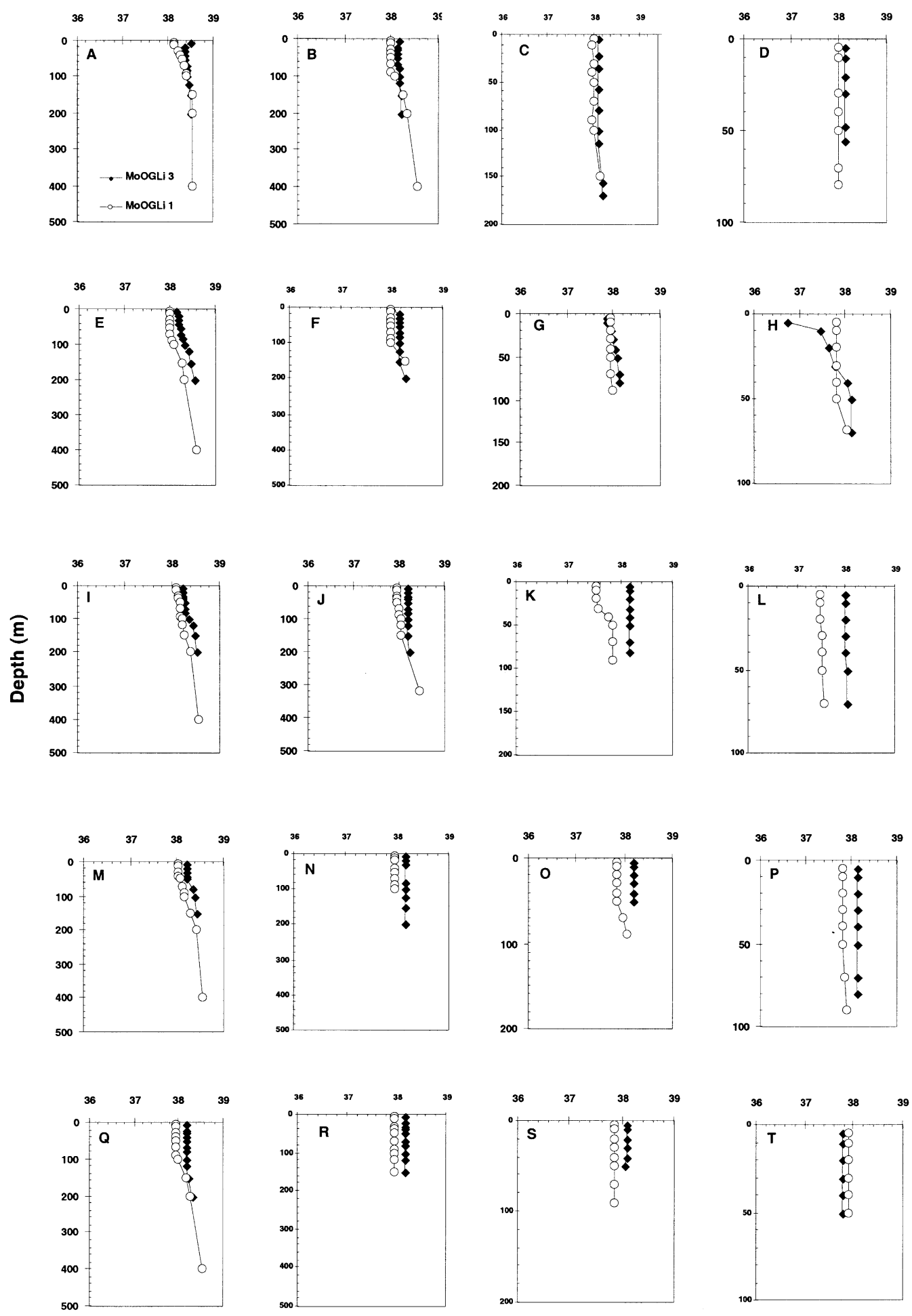

Fig. 3. Vertical profiles of salinityat the different stations of Moogli 1 and 3 cruises.

the two cruises (mean 0.8 and $0.7 \mu \mathrm{g} 1^{-1}$ ). Chl $a$ tended to increase westwards and near the coast. Contrarily to chlorophyll, primary production differed rather markedly according to the season. Its mean value was almost three times higher during Moogli 1 (401 $\mathrm{mg} \mathrm{C} \mathrm{m}^{-2} \mathrm{~d}^{-1}$ ) than during Moogli 3 (166 $\mathrm{mg} \mathrm{C} \mathrm{m}^{-2} \mathrm{~d}^{-1}$ ).

\subsection{Zooplankton composition}

For the purpose of the present work, a simple presentation of the main feature of zooplankton is indicated on Table 1. It appears that the general composition of the main zooplankton groups was very similar for the different cruises and 
Chlorophylle (mg m-3)
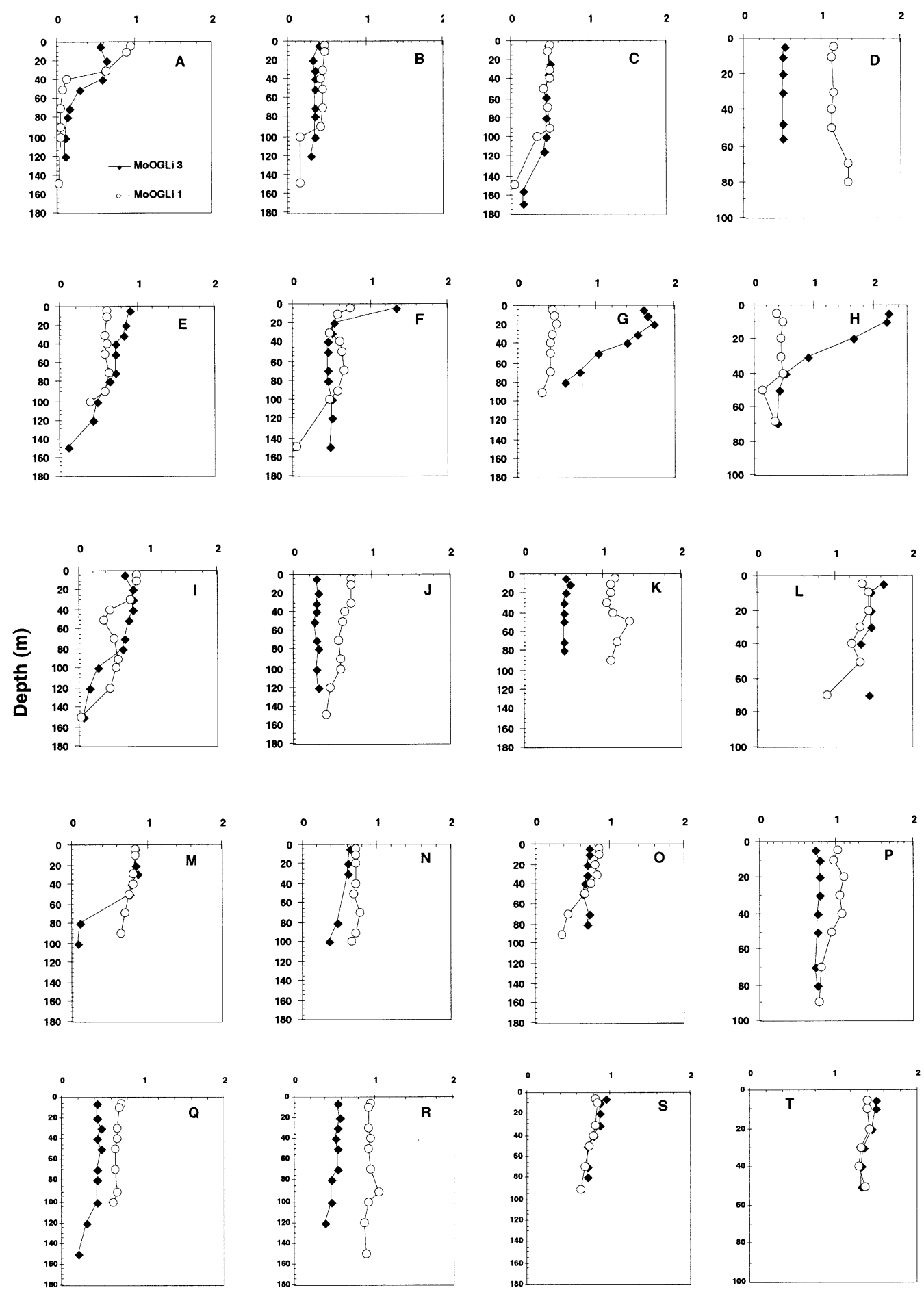

Fig. 4. Vertical profiles of chlorophyll $a$ at the different stations of Moogli 1 and 3 cruises.

stations. Copepods constitute the main taxon, and among them, Clausocalanus arcuicornis, the most important species (mean value for each of the cruise: $48.7 \%$ and $56.2 \%$ of total zooplankton). This species is followed in abundance by Oithona helgolandica (7.8-13.9\%) then by Oncaea mediterranea $(2.5-5.5 \%$, respectively).

\subsection{Zooplankton biomass}

The mean standing stock recorded during Moogli 1 (9.56 $\pm 4.73 \mathrm{mg}$ dry weight $(\mathrm{DW}) \mathrm{m}^{-3}$ ) was twice higher than during Moogli $3\left(4.73 \pm 2.53 \mathrm{mg} \mathrm{DW} \mathrm{m}^{-3}\right)$. The biomass increased near the coast and also varied according to the 

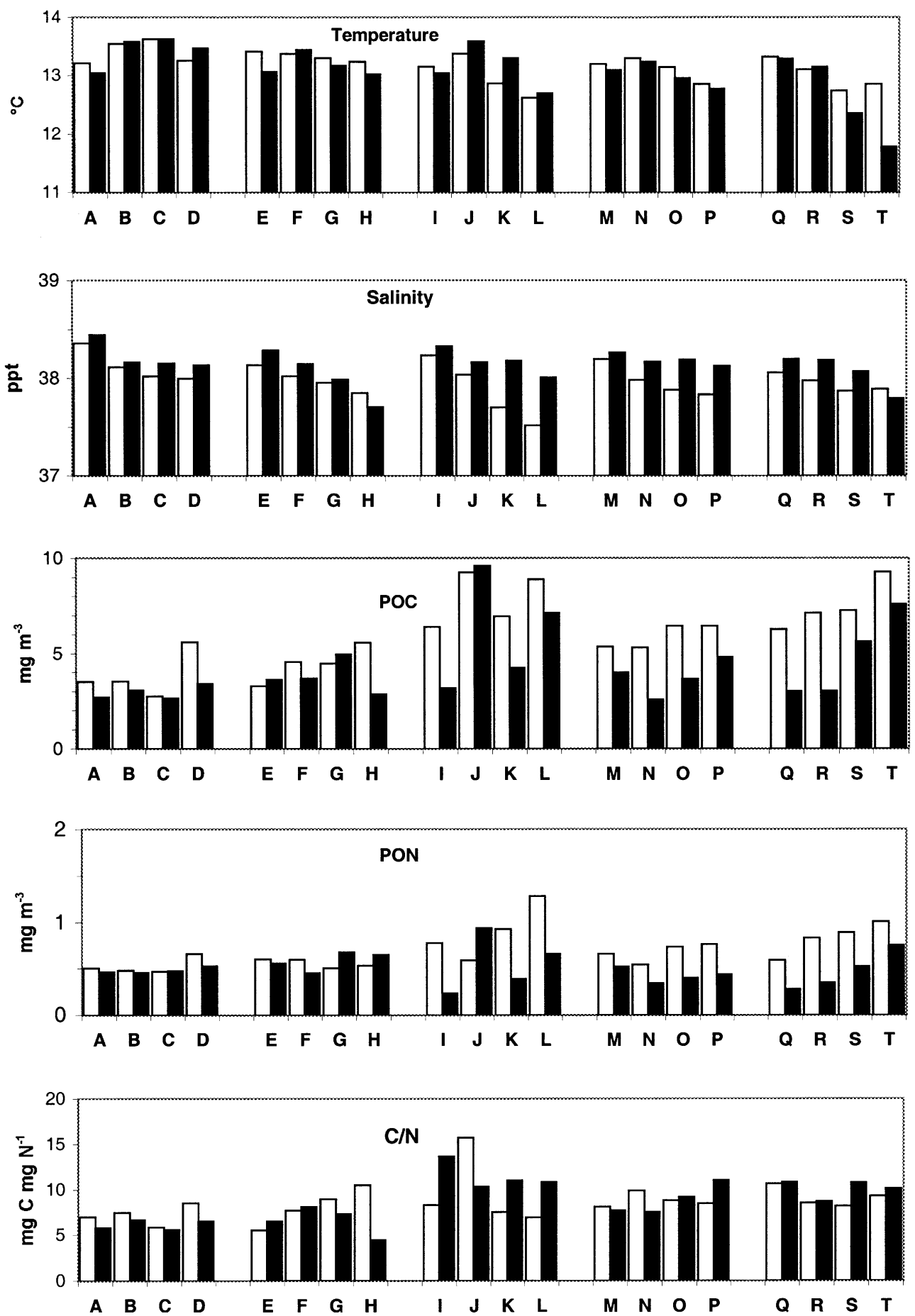

Fig. 5. Mean values (between 0 and $100 \mathrm{~m}$ ) of temperature, salinity, $\mathrm{POC}, \mathrm{PON}$ and $\mathrm{C} / \mathrm{N}$ ratio of the particulate organic matter at the different stations of Moogli 1 and 3 cruises.

longitude (Fig. 7). During Moogli 1, it was the lowest at the two eastern transects. During Moogli 3, few differences were noted between the different transects, except for slightly higher values at transect 3 .

Some differences in biomass appeared according to the type of net used (Fig. 7). At the two inner stations of each transect, the biomass obtained with the finer mesh $(80 \mu \mathrm{m})$ exceeded that collected with the coarse net (Wilcoxon test, $P<0.01$ ), while it was not significantly different at the two outer stations.

As regards relationships with environmental and biological factors, zooplankton biomass was inversely correlated to 

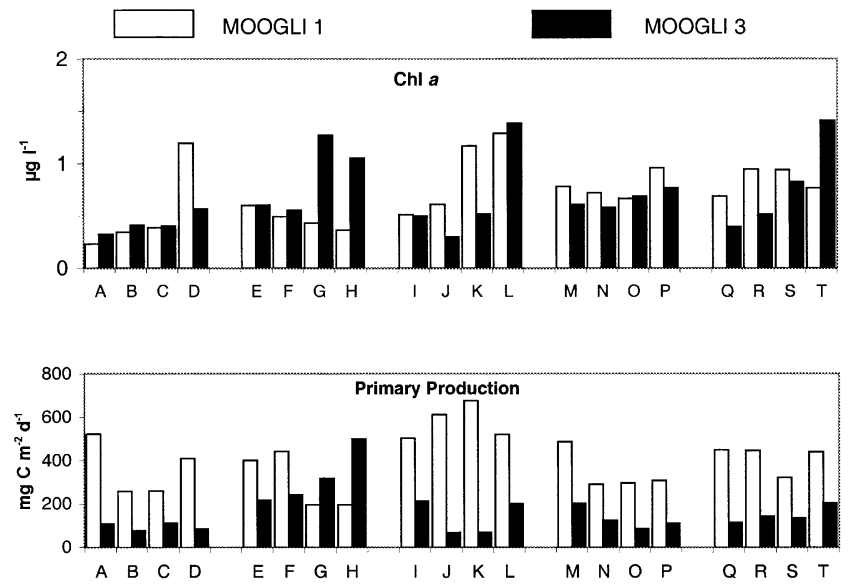

Fig. 6. Mean values (between 0 and $100 \mathrm{~m}$ ) of chlorophyll $a$ and value of primary production at the different stations of Moogli 1 and 3 cruises.
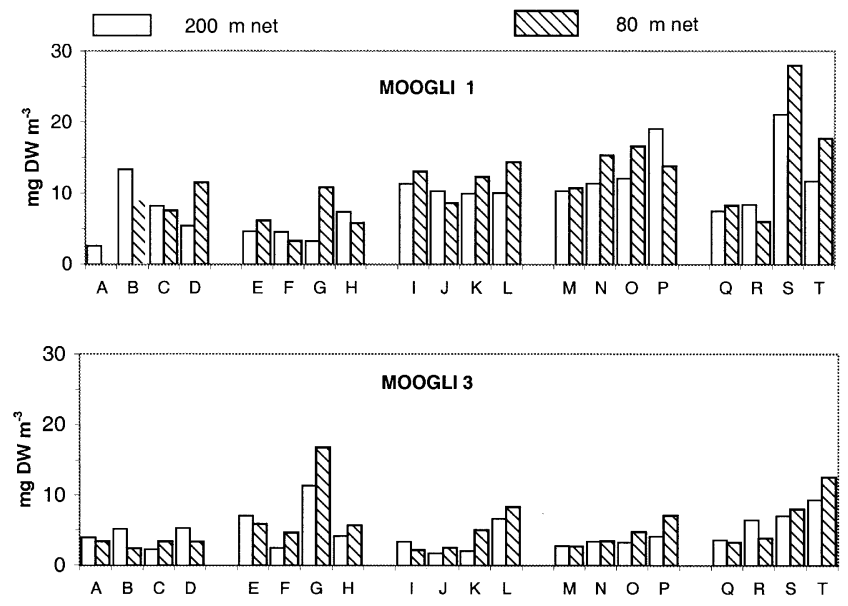

Fig. 7. Variation of zooplankton biomass (DW) using the 200 and $80 \mu \mathrm{m}$ nets at the different stations of Moogli 1 and 3 cruises.

temperature and salinity and positively to chlorophyll. It was also positively correlated to POC and PON during Moogli 1 and to primary production and PON during Moogli 3 (Table 2).

\subsection{Metabolism}

As no significant difference appeared in respiratory rates between zooplankton incubated in filtered or in natural seawater (Mann-Whitney test), results of these two types of experiments were pooled. Average respiratory rates (Fig. 8) were higher during Moogli $1\left(3.21 \pm 0.3 \mu \mathrm{O}_{2} \mathrm{mg}^{-1} \mathrm{~h}^{-1}\right)$ than during Moogli $3\left(2.06 \pm 0.4 \mu \mathrm{O} \mathrm{O}_{2} \mathrm{mg}^{-1} \mathrm{~h}^{-1}\right)$. According to the coast proximity, respiration was the lowest at the offshore stations in the eastern part of the gulf (transects 1 and 2 for Moogli 1, transect 1 for Moogli 3), while the inverse tendency was observed in almost all other cases. Minimum respiration rates were observed at the east of the gulf (transect 1) and also, at its central part (transect 3).

Ammonium excretion rates were three times higher during Moogli $1\left(30.6 \pm 4.9 \mu \mathrm{M} \mathrm{g}^{-1} \mathrm{~h}^{-1}\right)$ than during Moogli 3 $\left(9.5 \pm 2.9 \mu \mathrm{M} \mathrm{g}^{-1} \mathrm{~h}^{-1}\right)$. For Moogli 3, the values found at the distal stations of transects 3-5 were 1.8-10-fold higher than at the stations located near the coast, but differences between offshore and coastal stations were small at the two first transects. During Moogli 3, data from offshore and coastal stations were close. Excretion of phosphate showed similar mean values during the two seasonal surveys $(1.9 \pm 0.6$ and $\left.1.7 \pm 0.5 \mu \mathrm{M} \mathrm{g}^{-1} \mathrm{~h}^{-1}\right)$. During Moogli 1, phosphate excretion was maximum near the coast for transects 1 and 2 and offshore for transects 4 and 5. During Moogli 3, the maximum excretion was found close to the coast (transects 2, 4 and 5). For both cruises, at transect 3 , similar excretion rates were observed at proximal and distal stations. $\mathrm{O} / \mathrm{N}$ atomic ratio (calculated from respiration and ammonia excretion rates) was, on an average, twice as higher during Moogli 3 $(24.3 \pm 13.7)$ than during Moogli $1(12.2 \pm 4.5)$. Contrarily to Moogli 1 where the values found at the different stations were rather stable, strong variations occurred during Moogli 3: $\mathrm{O} / \mathrm{N}$ was considerably more elevated at the two stations of the first transect and near the coast, at transect 4 (Fig. 9). Average $\mathrm{O} / \mathrm{P}$ value (from respiration and phosphate excretion rates) was higher during Moogli $1(194 \pm 69)$ than during Moogli $3(117 \pm 54)$. During both cruises, marked maximums appeared offshore of the second transect, while the values were similar at the other stations. N/P ratio also showed higher mean values at Moogli $1(18.1 \pm 4.9)$ than at Moogli $3(7.89 \pm 2.08)$, as a consequence of the elevated ammonium excretion recorded during the first cruise. The values recorded offshore exceeded the coastal ones for all the transects.

No significant correlation was found between metabolic rates and environmental or biological factors, except for respiration, which was positively correlated to temperature during Moogli 1 , and $\mathrm{O} / \mathrm{N}$, inversely correlated to chlorophyll during Moogli 3 (Table 2).

\subsection{Ingestion of particle}

Particulate matter was ingested at verydifferent rates according to the stations, but with a similar pattern for the two cruises (Fig. 8). Ingestion was inversely correlated to the $\mathrm{C} / \mathrm{N}$ ratio of particles, and directly, to their concentration (Table 2 ). Strongest ingestion values were observed at the coastal stations of the two first transects, that is to say in the area most strongly influenced by the continental inputs from the Rhone river. The lowest values were found in the western part of the gulf.

\section{Discussion}

\subsection{Biomass distribution}

The contrast between the high zooplankton biomass recorded in spring and the low winter value is classical in most regions studied in the western Mediterranean (Gaudy, 1985) and particularly in the Gulf of Lions (Razouls and Kouwenberg, 1993; Gaudy and Champalbert, 1998). They are gener- 
Table 1

Relative abundance of main groups or species of zooplankton (\% of total number)

\begin{tabular}{|c|c|c|c|c|c|c|c|c|c|c|c|c|c|c|c|c|c|c|c|c|}
\hline Station & A & B & $\mathrm{C}$ & $\mathrm{D}$ & E & $\mathrm{F}$ & G & $\mathrm{H}$ & I & $\mathrm{J}$ & $\mathrm{K}$ & $\mathrm{L}$ & M & $\mathrm{N}$ & $\mathrm{O}$ & $\mathrm{P}$ & $\mathrm{Q}$ & $\mathrm{R}$ & $\mathrm{S}$ & $\mathrm{T}$ \\
\hline \multicolumn{21}{|l|}{ MOOGLI 1} \\
\hline \multicolumn{21}{|l|}{ Copepods } \\
\hline Clausocalanus arcuicornis & 48.32 & 51.71 & 50.29 & 42.39 & 68.25 & 40.29 & 41.22 & 23.11 & 66.43 & 66.99 & 23.41 & 37.38 & 74.27 & 83.44 & 51.94 & 34.10 & 50.07 & 40.70 & 40.74 & 38.91 \\
\hline Calanus helgolandicus & 2.35 & 0.60 & 1.15 & 3.01 & 0.18 & 1.44 & 1.47 & 2.40 & 2.01 & 0.56 & 23.02 & 5.57 & 0.91 & 0.23 & 12.14 & 7.83 & 0.78 & 1.60 & 9.38 & 5.78 \\
\hline Pleuromamma gracilis & 1.52 & 2.77 & 4.54 & 3.14 & 1.28 & 6.74 & 3.49 & 4.60 & 1.84 & 2.19 & 0.81 & 0.99 & 0.86 & 1.89 & 0.56 & 1.02 & 2.02 & 0.80 & 0.71 & 1.32 \\
\hline Centropages typicus & 1.39 & 2.98 & 0.00 & 1.63 & 2.45 & 1.31 & 1.30 & 1.00 & 2.45 & 3.22 & 11.75 & 10.40 & 1.83 & 2.81 & 10.28 & 12.79 & 7.15 & 0.67 & 7.63 & 14.17 \\
\hline Oithona helgolandica & 3.16 & 4.59 & 6.49 & 9.67 & 4.61 & 7.42 & 12.90 & 15.23 & 6.42 & 3.59 & 6.96 & 8.45 & 7.53 & 1.86 & 7.58 & 9.31 & 7.46 & 5.60 & 13.24 & 13.95 \\
\hline Oncaea mediterranea & 1.01 & 3.33 & 3.91 & 4.38 & 0.54 & 1.89 & 5.31 & 4.00 & 0.55 & 1.65 & 1.56 & 2.46 & 0.77 & 0.41 & 1.27 & 1.51 & 2.17 & 3.47 & 1.22 & 1.69 \\
\hline other species & 6.58 & 13.31 & 16.11 & 21.68 & 5.69 & 22.70 & 18.03 & 39.98 & 7.96 & 10.84 & 8.53 & 20.50 & 6.10 & 7.41 & 9.14 & $9.23^{2}$ & 12.28 & 19.47 & 13.14 & 10.82 \\
\hline Holoplankton & 34.68 & 19.58 & 13.61 & 1.84 & 16.28 & 16.76 & 12.21 & 1.58 & 11.27 & 9.83 & 6.04 & 6.30 & 6.89 & 0.60 & 4.81 & 4.85 & 16.21 & 21.82 & 8.12 & 4.82 \\
\hline Meroplankton & 1.00 & 1.12 & 3.90 & 12.26 & 0.72 & 1.45 & 4.07 & 8.11 & 1.08 & 1.12 & 17.92 & 7.95 & 0.84 & 1.35 & 2.28 & 19.38 & 1.86 & 5.86 & 5.81 & 8.54 \\
\hline \multicolumn{21}{|l|}{ MOOGLI 3} \\
\hline \multicolumn{21}{|l|}{ Copepods } \\
\hline Clausocalanus arcuicornis & 59.07 & 59.61 & 67.77 & 69.53 & 61.19 & 66.96 & 83.43 & 56.84 & 38.70 & 41.05 & 57.89 & 51.13 & 48.87 & 54.71 & 57.54 & 50.35 & 50.89 & 58.52 & 54.70 & 35.16 \\
\hline Calanus helgolandicus & 3.27 & 1.73 & 0.52 & 1.66 & 1.01 & 0.86 & 0.97 & 0.72 & 0.18 & 0.87 & 1.40 & 3.37 & 1.82 & 0.88 & 1.18 & 1.17 & 1.28 & 0.30 & 1.38 & 1.70 \\
\hline Pleuromamma gracilis & 5.95 & 6.18 & 2.93 & 1.46 & 3.82 & 3.02 & 0.32 & 2.16 & 10.08 & 10.65 & 3.25 & 2.67 & 4.99 & 5.55 & 3.61 & 4.32 & 6.67 & 0.91 & 1.56 & $1 / 90$ \\
\hline Centropages typicus & 4.57 & 1.26 & 0.35 & 0.79 & 1.54 & 0.09 & 1.48 & 1.41 & 0.17 & 0.00 & 0.62 & 1.95 & 2.20 & 0.55 & 1.04 & 1.32 & 0.77 & 1.94 & 3.17 & 12.84 \\
\hline Oithona helgolandica & 12.84 & 14.71 & 8.28 & 9.67 & 18.86 & 13.87 & 5.46 & 16.93 & 22.39 & 16.12 & 11.03 & 15.95 & 24.80 & 7.79 & 13.04 & 13.66 & 12.80 & 13.80 & 10.36 & 16.65 \\
\hline Oncaea mediterranea & 1.53 & 0.58 & 0.87 & 3.32 & 1.27 & 0.98 & 0.53 & 1.67 & 3.73 & 2.70 & 2.21 & 2.03 & 1.25 & 6.09 & 3.10 & 3.20 & 4.09 & 5.68 & 3.53 & 1.89 \\
\hline other species & 5.43 & 5.80 & 9.20 & -0.19 & 4.88 & 2.01 & -2.84 & 5.98 & 9.77 & 14.65 & 8.82 & 11.50 & 5.63 & 7.48 & 6.32 & 12.59 & 3.65 & -3.48 & 6.99 & 7.39 \\
\hline Holoplankton & 4.32 & 5.90 & 8.08 & 9.62 & 5.43 & 10.02 & 7.82 & 9.35 & 11.45 & 10.69 & 11.38 & 6.05 & 6.80 & 12.07 & 11.80 & 7.46 & 16.78 & 15.23 & 11.95 & 9.09 \\
\hline Meroplancton & 3.03 & 4.23 & 2.01 & 4.14 & 2.00 & 2.19 & 2.84 & 4.94 & 3.54 & 3.26 & 3.41 & 5.36 & 3.64 & 4.87 & 2.37 & 5.93 & 3.06 & 7.09 & 6.36 & 13.39 \\
\hline
\end{tabular}


Table 2

Value of the correlation coefficient between zooplankton biomass and different environmental parameters

\begin{tabular}{|c|c|c|c|c|c|c|c|c|c|}
\hline \multicolumn{10}{|c|}{ Zooplankton biomass } \\
\hline & & Temperature & Salinity & Chl $a$ & $\begin{array}{l}\text { Primary } \\
\text { production }\end{array}$ & $\mathrm{C}$ & $\mathrm{N}$ & $\mathrm{C} / \mathrm{N}$ & $\begin{array}{l}\text { Particle } \\
\text { concentration }\end{array}$ \\
\hline MOOGLI 1 & & $-0.57 * *$ & $-0.49 *$ & $0.43^{*}$ & 0.30 & $0.59 * *$ & $0.60 * *$ & 0.11 & -0.27 \\
\hline MOOGLI 3 & & $-0.58 * *$ & $-0.54 * *$ & $0.81 * *$ & $0.55 * *$ & 0.34 & $0.39 *$ & 0.02 & -0.15 \\
\hline \multicolumn{10}{|c|}{ Physiological activity } \\
\hline & Parameter & Temperature & Salinity & Chl $a$ & $\begin{array}{l}\text { Primary } \\
\text { production }\end{array}$ & $\mathrm{C}$ & $\mathrm{N}$ & $\mathrm{C} / \mathrm{N}$ & $\begin{array}{l}\text { Particle } \\
\text { concentration }\end{array}$ \\
\hline \multicolumn{10}{|l|}{ MOOGLI 1} \\
\hline & Respiration & $0.56^{*}$ & 0.08 & -0.13 & -0.13 & -0.24 & -0.26 & -0.01 & 0.31 \\
\hline & $\mathrm{N}$ excretion & 0.45 & 0.47 & -0.24 & 0.36 & -0.20 & -0.36 & 0.36 & -0.29 \\
\hline & P excretion & $0.60 *$ & 0.37 & -0.13 & 0.27 & -0.24 & -0.48 & 0.47 & 0.13 \\
\hline & $\begin{array}{l}\text { Food } \\
\text { ingestion }\end{array}$ & 0.36 & -0.02 & 0.01 & -0.48 & -0.19 & -0.32 & $-0.68 *$ & $0.81 * *$ \\
\hline & $\mathrm{O} / \mathrm{N}$ & -0.08 & -0.11 & 0.04 & -0.51 & 0.20 & 0.22 & -0.2 & 0.19 \\
\hline & $\mathrm{O} / \mathrm{P}$ & 0.26 & 0.10 & -0.13 & -0.08 & -0.33 & -0.04 & $-0.59 *$ & 0.07 \\
\hline & $\mathrm{N} / \mathrm{P}$ & 0.14 & 0.33 & -0.04 & 0.38 & -0.18 & -0.13 & 0 & 0.35 \\
\hline \multicolumn{10}{|l|}{ MOOGLI 3} \\
\hline & Respiration & 0.49 & -0.1 & -0.21 & -0.10 & -0.33 & 0.12 & -0.55 & 0.25 \\
\hline & $\mathrm{N}$ excretion & 0.09 & -0.32 & 0.02 & 0.37 & -0.06 & 0.37 & 0.40 & 0.02 \\
\hline & P excretion & -0.40 & -0.31 & 0.34 & 0.04 & 0.36 & 0.05 & 0.39 & -0.43 \\
\hline & $\begin{array}{l}\text { Food } \\
\text { ingestion }\end{array}$ & 0.41 & -0.17 & -0.09 & 0 & -0.19 & 0.29 & $-0.55^{*}$ & $0.79 * *$ \\
\hline & $\mathrm{O} / \mathrm{N}$ & 0.49 & 0.40 & $-0.68 *$ & -0.53 & -0.49 & -0.40 & -0.3 & 0.41 \\
\hline & $\mathrm{O} / \mathrm{P}$ & 0.29 & 0.34 & -0.39 & 0.29 & -0.20 & -0.15 & -0.07 & 0.01 \\
\hline & N/P & 0.13 & 0.3 & -0.18 & 0.09 & -0.16 & -0.09 & -0.01 & 0.17 \\
\hline
\end{tabular}

$(\mathrm{n}=20$, except for treatment with particle concentration $: \mathrm{n}=10) . *$ significant at $\mathrm{P}<0,05 ; * *$ significant at $\mathrm{P}<0,01$

ally linked to the spring increase of primary production, contrasting with winter scarcity (Conan et al., 1998). In our study, the seasonal increase of zooplankton biomass must be more related to primary production, which is significantly higher in spring, than to average chlorophyll concentration, which remains similar during the two cruises. Higher concentration of organic particulate matter (POC, PON) in spring could also contribute to create favorable food conditions for omnivorous animals such as most copepods. Temperature and salinity conditions, that were very similar for both cruises, could not have incidence on the parameters regulating the secondary production such as mortality or growth rates. On a spatial scale, zooplankton-standing stock is the highest in the central and western parts of the Gulf of Lions in March while more homogeneous values are found in all the gulf during winter. These differences would be related to the enrichment effect of the Rhone river. In spring, the Rhone influence is mainly marked at transects 2 and 3 as indicated by the decrease of salinity near the coast, but is still visible westwards, until transects 4 and 5. On the contrary, during winter, the Rhone effect is more limited, as suggested by the more homogeneous salinity distribution. Considering the coast-offshore distribution, in most cases the highest zooplankton biomass occurs near the coast. A similar result is shown by Razouls and Kouwenberg (1993) in the Gulf of Lions: when their biomass values (given in $\mathrm{g} \mathrm{m}^{-2}$ ) are transformed in units per $\mathrm{m}^{-3}$ the standing stocks in coastal stations are, in most cases, 2-10-fold higher than in offshore areas. This evidently results from the most favorable food conditions prevailing near the coast (POC, $\mathrm{PON}, \mathrm{Chl} a$, primary production), consequently to the input of continental water, while offshore waters are influenced by the NMC, characterized by its oligotrophic character (Gaudy and Champalbert, 1995; Conan et al., 1998). Table 2 confirms the role of the water masses identified by their physical or biological properties: zooplankton biomass is inversely related to temperature and salinity, two factors that mark the continental influence, and positively to trophic factors POC, PON, Chl $a$ and primary production. Nevertheless, some seasonal differences appear: during Moogli 3 biomass is strongly correlated to chlorophyll while this correlation is low for Moogli 1. Moreover, the correlation between zooplankton biomass and primary production is significant for Moogli 3 but not for Moogli 1. Thus, the influence of chlorophyll concentration and primary production on zooplankton standing stock seems paradoxically more marked in winter, a period during which primary production is yet weaker than in spring. This relative independence of zooplankton biomass from plant material in spring could be due to changes in its feeding regime, as discussed later.

The higher biomass obtained with $80 \mu \mathrm{m}$ nets could result from the greater retention of small detritus that are presumably more abundant near the coast. More likely is seems the consequence of the greater proportions of small organisms 

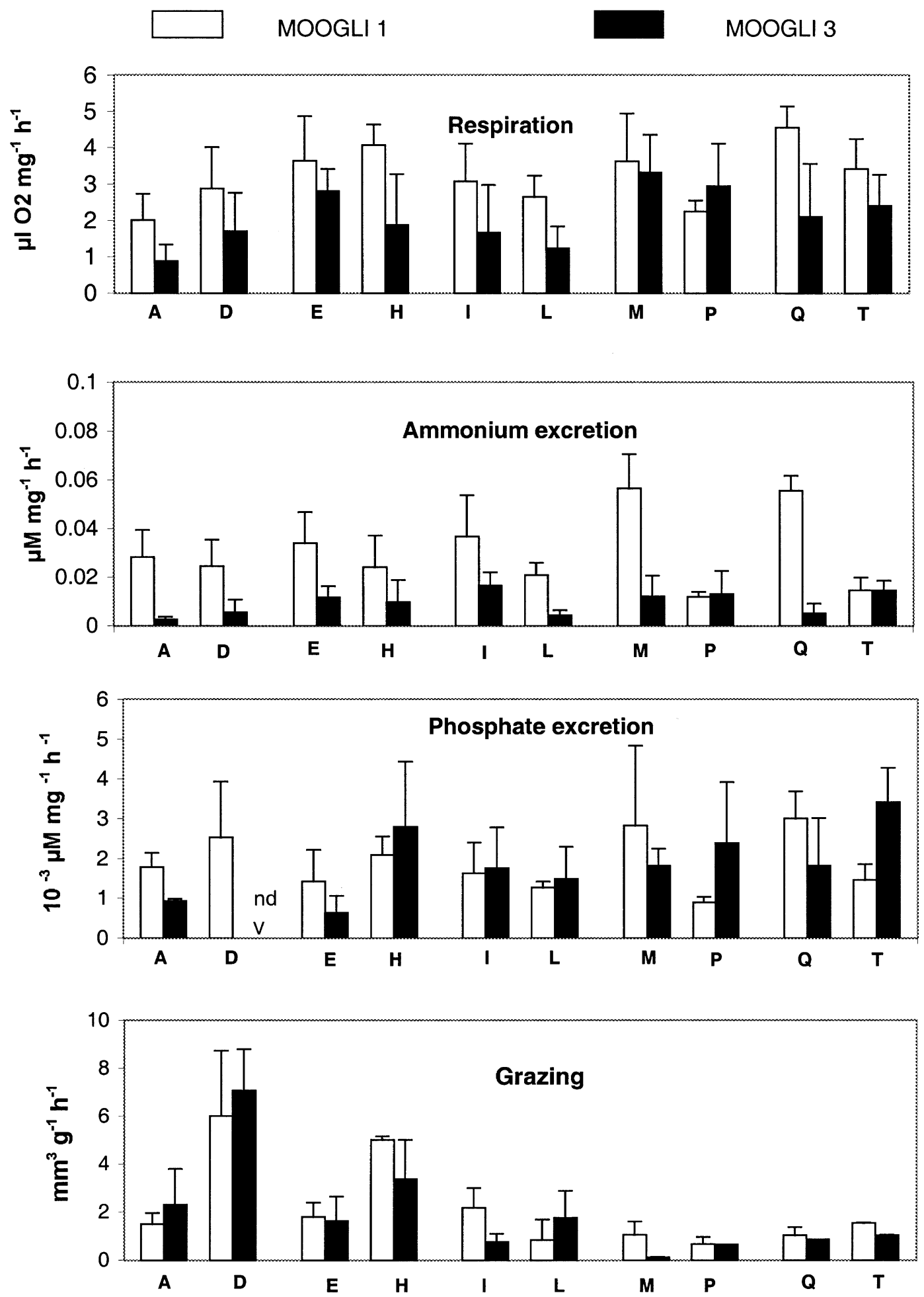

Fig. 8. Variations of respiration, nitrogen (ammonium) excretion, phosphorus (inorganic phosphate) excretion and particles ingestion at the different stations of Moogli 1 and 3 cruises. nd, no data.

such as meroplanktonic larvae or copepod nauplii, badly retained by the $200 \mu \mathrm{m}$ mesh (unpublished data). As these organisms are proportionally more abundant near the coast where many benthic (bivalve, echinids) or pelagic (copepods) animals develop, the difference in the biomass collected by the two types of nets is more marked there than offshore.

\subsection{Metabolism}

\subsubsection{Seasonal variation}

The higher mean rate of respiration recorded in spring is not the consequence of a seasonal thermal effect because temperature conditions were very similar during the two 

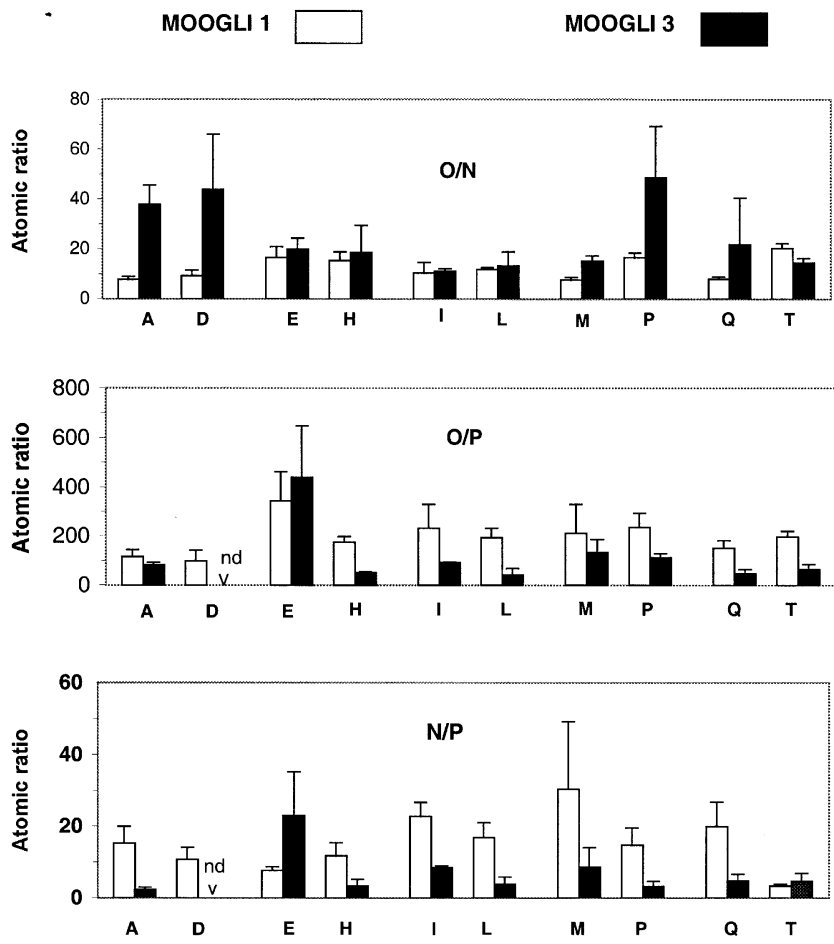

Fig. 9. Variations of $\mathrm{O} / \mathrm{N}, \mathrm{O} / \mathrm{P}$ and N/P atomic ratios at the different stations of Moogli 1 and 3 cruises. nd, no data.

cruises. Changes in zooplankton taxonomic composition or in average sizes of the individuals could explain this difference, because smaller organisms display higher specific rates than big animals (Gaudy, 1975). However, the size factor could not play a significant role because the average zooplankton composition was similar for both cruises (Table 1). The enhancement of respiration in spring would rather correspond to the increase of the general physiological activity of zooplankton and particularly of the growth and reproduction rates of most copepods which achieve their optimal development during spring or summer (Gaudy, 1985). Ammonium excretion was also markedly increased in spring, indicating a more intense catabolism of proteins. $\mathrm{O} / \mathrm{N}$ ratio is a good index of the quality of the food substrate (Le Borgne, 1986; Omori and Ikeda, 1984). High O/N values (>30) indicate the use of a food mainly composed of phytoplankton, with high carbohydrate and low protein contents. On the contrary, low $\mathrm{O} / \mathrm{N}$ values $(<10)$ suggest the use of animal food, rich in protein material and poor in carbohydrates (Omori and Ikeda, 1984; Le Borgne, 1986). The average O/N value obtained during Moogli 1 experiments (12.2) shows that the food probably contained a larger proportion of animal matter than during Moogli $3(\mathrm{O} / \mathrm{N}=24.3)$. This result seems surprising because primary production that was higher in spring, seemed proportionally less used as food by zooplankton than during winter. This can be explained by hypothesizing that plant food would be complemented by a food of animal nature to supply the additional energy necessary for the spring enhancement of the secondary production. On the contrary, during winter, a period when the physiological activity of zooplankton is generally depressed, most of the energy needed for secondary production would be met by feeding on phytoplankton. This is in accordance with the fact that zooplankton biomass, which is the end product of food activity via the production process, is strongly correlated to chlorophyll and primary production in winter while it is mainly correlated to POC and NOC in spring (Table 2).

\subsubsection{Spatial variations}

The respiratory rates recorded at the different stations of the gulf were positively related to temperature, significantly for Moogli 1 or approaching the significance level for Moogli 3. At the east of the gulf (transect 1), where the shelf is narrow, temperatures of coastal and offshore waters were not very different while at the other transects, the difference between colder coastal water and warmer open sea water was more marked. At these transects, the coastal stations were located in the enlarged part of the continental shelf, strongly influenced by the Rhone river and by other smaller coastal rivers (Hérault, Aude, Tech, Tet, Agli) flowing at the center or the west of the gulf (Coste, 1974). Moreover, coastal upwelling is relatively frequent in this region (Minas, 1968; Tournier, 1969). Low temperatures, resulting from continental influence or upwelling, would have a depressive effect on zooplankton metabolism near the coast. Similarly, ammonia excretion also increased at offshore regions, but without correlation with temperature. Probably another factor must be invoked: $\mathrm{O} / \mathrm{N}$ variations indicate that food must play an important role. Comparing $\mathrm{O} / \mathrm{N}$ values obtained in the coastal and the offshore stations at each transect, it appears that the highest $\mathrm{O} / \mathrm{N}$ is always found at the station where the chlorophyll concentration is maximum. From our data, in the Gulf of Lions, the nutritional strategy of zooplankton is mainly oriented towards the preferential utilization of plant material near the coast and mixed diet containing animal material, offshore, in the stations most frequently influenced by the NMC. During a seasonal survey at a fixed station off Marseilles (equivalent to Moogli's station C) Van Wambeke et al. (1996) have shown that the feeding strategy of zooplankton shifted from carnivore to herbivore regime, depending on the quality of the water surrounding the station (NMC oligotrophic water vs. richer coastal water). At this station a significant positive correlation was found between chlorophyll concentration and $\mathrm{O} / \mathrm{N}$. However, during Moogli cruises, at the scale of the whole gulf, no positive correlation was obtained between these two parameters. This could result from the statistical weight of the stations located on transect 3 , where the lowest $\mathrm{O} / \mathrm{N}$ values were observed while chlorophyll concentration and primary production displayed high values.

Relationship with primary production: A strong correlation between food ingestion and particle concentration is classically observed in zooplankton (Frost, 1972). Thus, it is consistent to note that, for both cruises, the highest ingestion values were observed at stations $\mathrm{D}$ and $\mathrm{H}$, near the Rhone river discharge. The nature of suspended particles (organic fraction) cannot be stated by the coulter counter technique, 
but it can be supposed that the energy value of particles must be low near the coast, due to the input of mineral matter from land origin (Durrieu de Madron et al., 2000). This is also suggested by the poor chlorophyll concentration measured in spring at station $\mathrm{H}$, in the plume region, where the abundance of particles was very high. The bad nutritional quality of particulate matter must contribute to depress the secondary production process, explaining the low zooplankton biomass recorded at transect 2 . Similarly, in the Gironde estuary, the lowest abundance of the copepod Eurytemora is found in the most turbid zone (Castel and Feurtet, 1989). In a neritic area strongly submitted to continental influence, it is likely that particulate matter contains an important and variable fraction of inorganic material (Durrieu de Madron et al., 2000). Therefore, it seems unrealistic to evaluate the assimilation of food from the ingestion of suspended matter. It is more justified to calculate indirectly the amount of digestible food from zooplankton respiratory and growth needs. The input of carbon necessary to balance the respiratory needs can be calculated from the respiration rate $(R)$ the respiratory quotient (RQ) and the assimilation rate $(A)$. As the food was supposed to contain relatively more proteins than carbohydrates, as inferred from the average value of $\mathrm{O} / \mathrm{N}$, a $\mathrm{RQ}$ of 0.85 was chosen (Omori and Ikeda, 1984). The value adopted for A, was 0.8, based on Conover's (1966) data and Mauchline (1998) review. The equivalence of respiration as assimilated carbon was $C_{1}=(R / 22.4) \times 12 \times 0.85$. Ingested carbon was calculated according to $C_{2}=C_{1} A^{-1}$. The assimilated carbon must also account for production $(P)$, i.e. growth and reproduction needs. The quantity of carbon necessary to balance production and respiration can be roughly estimated using the net growth efficiency $K_{2}=P(P+R)^{-1}$. The value of carbon ration is calculated according to $C_{3}=R\left(1-K_{2}\right)^{-1}$. In our calculations, we adopted the value of 0.4 for $K_{2}$, from the average data reviewed by Mauchline (1998). Ingested carbon was then calculated according to the relation $C_{4}=C_{3} A^{-1}$.

The grazing impact is the ratio between daily carbon ingestion by zooplankton population (specific rate multiplied by zooplankton biomass) and primary production. Table 3 shows the results obtained at the two Moogli cruises. For each station, two values are presented. The first corresponds to the minimal needs (respiration only) while the second takes also into account the growth and reproduction needs indirectly calculated from an average $K_{2}$ of 0.4 . The mean carbon necessary for respiration accounts for $22 \%$ of the primary production at offshore stations and $14 \%$, near the coast. These values are close to the values of $20-23 \%$ given by Alcaraz (1988) for the routine metabolism of zooplankton in the Balearic region, at similar temperatures. Considering the carbon required for secondary production needs, in most stations, grazing represents an important part of the primary production, particularly at offshore stations. Thus, in the Gulf of Lions, during the investigated period, zooplankton contributes significantly to the regulation of primary production. The minimal quantity of carbon used for respiratory needs represents, according to the stations, $1.7-16 \%$ of the body- carbon per day, during Moogli 1 and 3-10\%, during Moogli 3 . The carbon necessary to balance metabolism and secondary production needs corresponds to 17-40\% (average $27.5 \%$ ) of the body carbon at Moogli 1 and to 7-25\% (average 17\%) at Moogli 3. All these values are in the range of literature data for similar temperature conditions (Mauchline, 1998).

By its excretion products, the zooplankton also contributes to the pool of nutrients available for the primary production. The total excretion by zooplankton population is the product of specific excretion rates and zooplankton biomass (Table 3). The nitrogen or phosphorus requirements for primary production are estimated from the Redfield ratio (atomic ratio $\mathrm{C} / \mathrm{N}=6.6$ and $\mathrm{N} / \mathrm{P}=16$ ). The average zooplankton nitrogen contribution to primary production is higher during Moogli 1 (31\%) than during Moogli 3 (10\%). Excreted phosphorus provides, on average $16 \%$ of the primary production needs at Moogli 1 and $27 \%$ at Moogli 3. The excreted $\mathrm{N}$ and $\mathrm{P}$ contribute to a more important part of the needs of primary production offshore (Table 3 ). The values of nitrogen contribution are in the range of most literature data (review of Le Borgne, 1986). In the Balearic region, the excretion of zooplankton provided $14-17 \%$ of the $\mathrm{N}$ requirement for primary production (Alcaraz, 1988). The average zooplankton contribution in $P$ is lower in the Gulf of Lions than in the Balearic region studied by Alcaraz (1988) where the values range between $27 \%$ and $109 \%$ of the primary production requirement. Values of $P$ excretion exceeding $100 \%$ of the primary production demand have also been recorded in an oligotrophic area (North Pacific Gyre), by Eppley et al. (1973). Near the coast, except at station H where the primary production demand was low, the role of zooplankton as a nitrogen or phosphorus provider is more limited. As a matter of fact, most of the phytoplankton demand must be satisfied by the nutrients input from the land as observed in estuarine environments by Smith (1978). This contrasts with the observations of Alcaraz et al. (1994) for the Catalan Sea: nitrogen excreted by zooplankton in coastal or frontal regions accounted for about six times that of offshore stations. The secondary production is very difficult to assess from egg production experiments that do not necessarily reflect the in situ conditions and show strong variations according to the different species (Saiz et al., 1997). A rough estimation of production can be inferred from the mean respiration rate and $K_{2}(0.4)$ values according to the formula $P=R W K_{2}\left(1-K_{2}\right)^{-1}$, where $P$ is the production, $R$, the specific respiration rate and $W$, the zooplankton biomass. The mean production value is $54 \mathrm{mg} \mathrm{C} \mathrm{m}^{-2} \mathrm{~d}^{-1}$ at Moogli 1 and 19 mg C m${ }^{-2} \mathrm{~d}^{-1}$ at Moogli 3. The transfer efficiency is better offshore than near the coast (Table 3). As an average it represented $13 \%$ and $12 \%$ of the primary production for each cruise. These values, which exceed the usual value of 10 (Ikeda and Motoda, 1977), show a good functioning of the first links of the pelagic food chain in the Gulf of Lions. This efficiency of the food chain could contribute to explain the 
Table 3

Values of primary production, zooplankton biomass, respiration, ammonium and phosphate excretion rates, grazing impact, secondary production and ecological efficiency at the different stations of MOOGLI cruises

\begin{tabular}{|c|c|c|c|c|c|c|c|c|c|c|}
\hline \multirow[t]{3}{*}{ Station } & \multirow{3}{*}{$\begin{array}{l}\text { Primary } \\
\text { Production } \\
\quad\left(\mathrm{mg} \mathrm{C} \mathrm{m}^{-2} \mathrm{~d}^{-1}\right)\end{array}$} & \multicolumn{5}{|l|}{ Zooplankton } & \multicolumn{2}{|c|}{ Grazing impact } & \multirow{3}{*}{$\begin{array}{c}\text { Secondary } \\
\text { production } \\
\left(\mathrm{mg} \mathrm{C} \mathrm{m}^{-2} \mathrm{~d}^{-1}\right)\end{array}$} & \multirow{3}{*}{$\begin{array}{c}\begin{array}{c}\text { Ecological } \\
\text { efficiency }\end{array} \\
\text { SP. PP } P^{-1}(\%)\end{array}$} \\
\hline & & \multirow{2}{*}{$\begin{array}{c}\text { Respiration } \\
\left(\mathrm{mg} \mathrm{C} \mathrm{m}^{-2} \mathrm{~d}^{-1}\right) \\
\end{array}$} & \multicolumn{2}{|c|}{ Ammonium excretion } & \multicolumn{2}{|c|}{ Phosphate excretion } & minimum & maximum & & \\
\hline & & & $\left(\mu \mathrm{MN} \mathrm{m}^{-2} \mathrm{~d}^{-1}\right)$ & $\left(\% \mathrm{PP} \mathrm{d}^{-1}\right)$ & $\left(\mu \mathrm{MP} \mathrm{m}^{-2} \mathrm{~d}^{-1}\right)$ & $\left(\% \mathrm{PP} \mathrm{d}^{-1}\right)$ & \multicolumn{2}{|c|}{$\left(\% \mathrm{PP} \mathrm{d}^{-1}\right)$} & & \\
\hline \multicolumn{11}{|l|}{ MOOGLI 1} \\
\hline A & 522 & 22.05 & 678 & 10.4 & 21.6 & 5.4 & 5.3 & 8.8 & 14.7 & 2.8 \\
\hline $\mathrm{D}$ & 410 & 27.76 & 522 & 10.2 & 27.5 & 8.8 & 8.5 & 14.1 & 18.5 & 4.5 \\
\hline E & 399 & 71.82 & 477 & 9.6 & 31.0 & 9.9 & 22.5 & 37.6 & 47.9 & 12.0 \\
\hline $\mathrm{H}$ & 196 & 52.41 & 665 & 27.1 & 29.3 & 19.0 & 33.4 & 55.8 & 34.9 & 17.8 \\
\hline I & 503 & 152.75 & 3798 & 60.3 & 87.7 & 22.2 & 38.0 & 63.4 & 101.8 & 20.2 \\
\hline $\mathrm{L}$ & 519 & 48.03 & 689 & 10.6 & 25.6 & 6.3 & 11.6 & 19.3 & 32.0 & 6.2 \\
\hline M & 487 & 190.96 & 5459 & 89.5 & 138.6 & 36.2 & 41.3 & 69.0 & 107.3 & 22.1 \\
\hline $\mathrm{P}$ & 307 & 80.59 & 665 & 17.3 & 35.5 & 14.7 & 32.8 & 54.8 & 53.7 & 17.5 \\
\hline Q & 448 & 146.79 & 3904 & 69.5 & 107.5 & 30.5 & 41.1 & 68.4 & 97.9 & 21.8 \\
\hline $\mathrm{T}$ & 440 & 52.08 & 323 & 5.9 & 24.5 & 7.1 & 14.8 & 24.7 & 34.7 & 7.9 \\
\hline \multicolumn{11}{|c|}{ MOOGLI 3} \\
\hline A & 106 & 15.39 & 95 & 7.2 & 34.7 & 20.8 & 18.2 & 30.3 & 10.3 & 9.7 \\
\hline $\mathrm{D}$ & 83 & 15.74 & 164 & 15.8 & 8.1 & 6.2 & 23.7 & 39.6 & 10.5 & 12.6 \\
\hline E & 215 & 85.62 & 789 & 29.3 & 42.1 & 12.5 & 49.8 & 83.1 & 57.1 & 26.5 \\
\hline $\mathrm{H}$ & 499 & 14.29 & 165 & 2.6 & 56.9 & 7.3 & 3.6 & 6.0 & 9.5 & 1.9 \\
\hline I & 211 & 23.08 & 173 & 6.6 & 78.9 & 23.8 & 13.7 & 22.8 & 15.4 & 7.3 \\
\hline $\mathrm{L}$ & 200 & 11.54 & 149 & 6.0 & 85.5 & 27.2 & 7.2 & 12.0 & 7.7 & 3.8 \\
\hline $\mathrm{M}$ & 202 & 39.85 & 229 & 9,00 & 66.2 & 20.8 & 24.7 & 41.2 & 26.6 & 13.2 \\
\hline $\mathrm{P}$ & 109 & 21.93 & 86 & 6.3 & 156.4 & 91.2 & 25.2 & 42.0 & 14.6 & 13.4 \\
\hline Q & 114 & 32.80 & 164 & 11.5 & 56.0 & 31.2 & 36.0 & 60.1 & 21.9 & 19.2 \\
\hline $\mathrm{T}$ & 205 & 25.21 & 160 & 6.2 & 81.5 & 25.3 & 15.4 & 25.7 & 16.8 & 8.2 \\
\hline
\end{tabular}


success of pelagic fisheries in this area, mainly for the anchovy (Plounevez and Champalbert, 2000).

\section{Conclusion}

In the Gulf of Lions, the distribution of zooplankton biomass is rather heterogeneous despite its limited geographical extent. Biomass increases according to an offshore-coastal gradient and an east-west gradient. The input of continental water (mainly the Rhone river) results in lower temperature and salinity conditions near the coast, and in richer food conditions for zooplankton (increase of PON, POC and chlorophyll concentration and of primary production). In winter, this enrichment is limited to the area close to the Rhone discharge, but in spring, when the freshwater input is more important, it influences all the central and western part of the Gulf. On the contrary, offshore regions display poorer food conditions due to the oligotrophic character of the NMC. The geographical and temporal variations of zooplankton biomass are positively linked to the level of the primary production but also depend on the quality of food. In spring, the increase of food energy necessary to account for the seasonal enhancement of the zooplankton biomass needs a complement of phytoplankton food by another source of food, of animal nature, as suggested by the lower $\mathrm{O} / \mathrm{N}$ values of the particulate material. On the contrary, in winter, plant food seems sufficient for the maintenance of the lower zooplankton biomass observed at this season.

\section{References}

Alcaraz, M., 1988. Summer zooplankton metabolism and its relation to primary production in the western Mediterranean. Oceanol. Acta special issue no. 9, 185-188.

Alcaraz, M., Saiz, E., Estrada, M., 1994. Excretion of ammonia by zooplankton and its potential contribution to nitrogen requirements for primary production in the Catalan Sea (NW Mediterranean). Mar. Biol. $119,69-76$.

Boucher, J., Thiriot, A., 1972. Zooplancton et micronecton estivaux des deux cents premiers mètres en Méditerranée occidentale. Mar. Biol. 15, $47-56$.

Castel, J., Feurtet, A., 1989. Dynamics of the copepod Eurytemora affinis hirundoides in the Gironde estuary: origin and fate of its production. In: Ros, J.D. (Ed.), Topics in Marine Biology. Scient. Marina 53, 577-584.

Conan, P., Pujo Pay, M., Raimbault, P., Leveau, M., 1998. Variabilité hydrologique et biologique au sein du courant nord Méditerranéen à l'entrée du golfe du Lion. II. Bilan de la productivité sur le bord interne du courant. Oceanol. Acta 21, 767-781.

Conover, R.J., 1966. Assimilation of organic matter by zooplankton. Limnol. Oceanogr. 11, 338-345.

Coste, B., 1974. Rôle des apports nutritifs rhôdaniens sur la production organique des eaux du golfe du Lion. Tethys 6, 727-740.

Coste, B., Jacques, G., Minas, H.J., 1977. Sels nutritifs et production primaire dans le golfe du Lion et ses abords. Ann. Inst. Oceanogr., Paris 53, 189-202.

Durrieu de Madron, X., Abassi, A., Heussner, S., Monaco, A., Aloisi, J.C., Radakovitch, O., Giresse, P., Buscail, R., Kerhervé, P.H., 2000. Particulate matter and organic carbon budgets for the Gulf of Lions (NW Mediterranean). Oceanol. Acta 23, 717-730.
Eppley, R.W., Renger, E.H., Venrick, E.L., Mullin, M.L., 1973. A study of plankton dynamics and nutrients cycling in the central gyre of the north Pacific Ocean. Limnol. Oceanogr. 18, 534-551.

Fiztwater, S.E., Knauer, G.A., Martin, J.J., 1982. Metal contamination and its effect on primary production measurements. Limnol. Oceanogr. 24, 544-551.

Frost, B.W., 1972. Effects of size and concentration of food particles on the feeding behavior of the marine planktonic copepod Calanus pacificus. Limnol. Oceanogr. 17, 805-815.

Furnestin, J., 1960. Hydrologie de la Méditerranée occidentale (golfe du Lion), mer catalane, mer d'Alboran, Corse orientale, (14 juin-20 juillet 1957). Rec. Trav. Inst. Pêches Marit. 24, 5-120.

Gaudy, R., 1975. Étude de la respiration chez les copépodes pélagiques méditerranéens (bassin occidental et Mer Ionienne) et de ses variations en fonction de la bathymétrie des espèces et de leur origine géographique. Mar. Biol. 29, 109-118.

Gaudy, R., 1985. Features and peculiarities of zooplankton communities from the western Mediterranean. In: Apostolopoulou, M., Kiortsis, V. (Eds.), Mediterranean Marine Ecosystems. Plenum Press, New York and London, pp. 297-303.

Gaudy, R., Champalbert, G., 1998. Space and seasonal quantitative variations of zooplankton at the south of Marseille (France). Oceanol. Acta 21, 793-802.

Ikeda, T., Motoda, S., 1977. Estimated zooplankton production and their ammonia excretion in the Kuroshio and adjacent seas. Fish. Bull. 76 (2), 357-367.

Koroleff, F., 1969. Direct determination of ammonia in natural waters as indophenol blue. Council for the Exploration of the Sea. Comm. Meeting C9, 1-6.

Le Borgne, R., 1986. The release of soluble end products of metabolism. In: Corner, E.D.S., O'Hara, S.Z.C.M. (Eds.), The Biological Chemistry of Marine Copepods. Oxford University Press, Oxford, pp. 109-164.

Lefèvre, D., Minas, H.J., Robinson, C., Williams, P.J., Woodward, E.M.S., 1997. Review of gross community production and dark respiration in the gulf of Lions. Deep-Sea Res. 44, 801-832.

Mauchline, J., 1998. The biology of Calanoid copepods. Adv. Mar. Biol. 33, $1-707$.

Millot, J., 1979. Wind-induced upwellings in the Gulf of Lions. Oceanol. Acta 2, 261-274.

Millot, J., Crepon, M., 1990. The Gulf of Lions' hydrodynamics. Cont. Shelf Res. 10, 885-894.

Millot, J., Wald, L., 1980. The effects of Mistral wind on the Ligurian Current near Provence. Oceanol. Acta 4, 399-402.

Minas, H.J., 1968. Recherche sur la production organique primaire dans le bassin méditerranéen nord-occidental. Rapport avec les phénomènes hydrologiques. These Doct. Sci. Univ. Aix-Marseille. pp. 250 p.

Minas, H.J., Minas, M., 1989. Primary production in the Gulf of Lion with considerations on Rhone river inputs. In: Martin, J.M., Barths, H. (Eds.), Water Pollution Research Reports 13. "Eros 2000”, pp. 112-125.

Morel, A., Bricaud, A., André, J.M., Pelaez-Hudlet, J., 1990. Spatialtemporal evolution of the Rhone plume as seen by CZCS imagery. Consequences upon the primary production in the Gulf of Lions. In: Martin, J.M., Barths, H. (Eds.), Water Pollution Research Reports, 20. "Eros 2000", pp. 45-62.

Omori, M., Ikeda, T., 1984. Methods in Marine. Zooplankton Ecology. Wiley, New York, pp. 332.

Péres, J.M., 1982. Zonations. In: Kinne, O. (Ed.), Marine Ecology, 2. Wiley, pp. 9-45.

Plounevez, S., Champalbert, G., 2000. Diet, feeding behaviour and trophic activity of the anchovy (Engraulis encrasicolus L.) in the Gulf of Lions (Mediterranean Sea). Oceanol. Acta 23, 175-192.

Raimbault, P., Rodier, M., Taupier-Letage, I., 1988. Size fractionation of phytoplankton in the Ligurian Sea and thealgerian Basin (Mediterranean sea): size fraction versus total concentrations. Mar. Microbial Food Webs $3,1-7$. 
Raimbault, P., Diaz, F., Boudjellal, B., 1999. Simultaneous determination of particulate forms of carbon, nitrogen and phosphorus collected on filters using a semi-automatic wet-oxidation procedure. Mar. Ecol. Progr. Ser. 180, 289-295.

Razouls, C., Kouwenberg, J.H.M., 1993. Spatial distribution and seasonal variation of mesozooplankton biomass in the Gulf of Lions (north western Mediterranean. Oceanol. Acta 16, 393-401.

Saiz, E., Calbet, A., Trepat, I., Irigoien, X., Alcaraz, M., 1997. Food availability as a potential source of bias in the egg production method for copepods. J. Plankt. Res. 19, 1-14.

Smith, S.L., 1978. The role of zooplankton in the nitrogen dynamics of a shallow estuary. Est. Coast. Mar. Sci. 7, 555-565.

Steeman-Nielsen, E., 1952. The use of radioactive carbon (14C) for measuring organic production in the sea. J. Cons. Int. Explor. Mer. 18, 117-140.
Strickland, J.D.H., Parson, T.R., 1972. A practical handbook of sea-water analysis. Bull. Fish Res. Can. 125, 311.

Tournier, H., 1969. Hydrologie saisonnière du golfe du Lion. Rev. Trav. Inst. Pêches Marit. 33, 265-300.

UNESCO, 1968. Monographs on oceanographic methodology. 2. Zooplankton Sampling. UNESCO, Paris, pp. 153-159.

Van Wambeke, F., Christaki, U., Gaudy, R., 1996. Carbon fluxes from the microbial food web to mesozooplankton. An approach in the surface layer of a peragic area (NW Mediterranean Sea). Oceanol. Acta 19, $57-66$.

Yentsch, C.S., Menzel, D.W., 1963. A method for determination of phytoplankton chlorophyll and phaeophytin by fluorescence. Deep-Sea Res. $10,211-231$. 